\title{
Association of microRNA-146a and their target gene IRAK-1 polymorphism with enthesitis related arthritis category of juvenile idiopathic arthritis
}

\author{
Sushma Singh ${ }^{1 *}$, Geeta Rai ${ }^{2}$, Amita Aggarwal $^{1}$ \\ From International Conference on Human Genetics and 39th Annual Meeting of the Indian Society of \\ Human Genetics (ISHG) \\ Ahmadabad, India. 23-25 January 2013
}

\section{Background}

MicroRNAs (miRNAs) are non-coding RNA molecules that play pivotal role in modulating the expression of multiple target genes at the post-transcriptional level. Single Nucleotide Polymorphisms (SNP) in pre-miRNAs can alter miRNA expression, and polymorphism in target molecules can affect binding to target mRNA. Studies have shown an association between miR-146a polymorphisms and autoimmune disease. Taking into account that interleukin-1 receptor-associated kinase-1 (IRAK-1) is a target of miR-146a, we studied the association between SNPs of miRNA-146 and its target IRAK-1 with susceptibility to Juvenile Idiopathic Arthritis-Enthesitis Related Arthritis (JIA-ERA).

\section{Methods}

One hundred and fifty patients with JIA-ERA (ILAR criteria) were included in the study. 216 blood donors (201 male) with a mean age of 30.5 years served as controls. miR-146a (C/G) (rs2910164) and it's target IRAK-1(C/T) (rs1059703) at Exon 12 region and IRAK-1 (A/C) (rs3027898) at 3'UTR polymorphisms were analyzed using PCR-RFLP method.

\section{Results}

Among 150 patients, 134 were males and the mean age at onset of disease was 11 (4-16) years, mean disease duration was $4.5(0.3-12)$ years. 22 had uveitis and 21 had positive family history. 73 had enthesitis and 75 had inflammatory back pain and all had arthritis. 116 were HLA B27 positive.

Genotype frequency of miR-146a gene was in Hardy Weinberg equilibrium in healthy controls whereas in IRAK-1 genotype the frequency was contrary owing to its presence on chromosome $\mathrm{X}$.

The genotype frequency for miR-146a were different in controls and patients [GG (51.85\% vs $50.0 \%)$, GC $(42.13 \%$ vs $37.29 \%)$ and CC (6.02\% vs $12.71 \%)$, OR $=2.18 ; 95 \%$ CI $1.02-4.68$; $\mathrm{p}$ value $=0.0418]$

IRAK-1 (rs1059703) allelic frequencies in controls and patients were similar [CC (33.8\% vs $32.9 \%)$, and TT (66.2\% vs $67.0 \%)]$. IRAK-1 (rs3027898) allelic frequencies were also similar among control and patients [CC (70.1\% vs $76.1 \%)$ and AA ( $29.8 \%$ vs $23.9 \%)]$.

\section{Conclusion}

The CC genotype of the miR-146a rs2910164 polymorphism was significantly associated with the susceptibility to JIA-ERA.

\section{Authors' details}

'Department of Clinical Immunology, Sanjay Gandhi Post Graduate Institute of Medical Sciences, Lucknow, India. ${ }^{2}$ Department of Molecular and Human Genetics, Faculty of Science, Banaras Hindu University, Varanasi, India.

\footnotetext{
* Correspondence: sushma2502@gmail.com

'Department of Clinical Immunology, Sanjay Gandhi Post Graduate Institute of Medical Sciences, Lucknow, India

Full list of author information is available at the end of the article
} 
doi:10.1186/1755-8166-7-S1-P69

Cite this article as: Singh et al:: Association of microRNA-146a and their target gene IRAK-1 polymorphism with enthesitis related arthritis category of juvenile idiopathic arthritis. Molecular Cytogenetics 20147 (Suppl 1):P69.

Submit your next manuscript to BioMed Central and take full advantage of:

- Convenient online submission

- Thorough peer review

- No space constraints or color figure charges

- Immediate publication on acceptance

- Inclusion in PubMed, CAS, Scopus and Google Scholar

- Research which is freely available for redistribution

Submit your manuscript at www.biomedcentral.com/submit
C Biomed Central 